\title{
Ore Production Optimization for Constant Grade of Run-of-Mine Feed to the Beneficiation Plant of National Iron Ore Mining Company, Itakpe, Nigeria
}

\author{
*Nwosu J.I, Adetola D.O \\ Department of Geology, University of Port Harcourt, Nigeria
}

\begin{abstract}
*Corresponding Author: Nwosu J.I, Department of Geology, University of Port Harcourt, Nigeria
\end{abstract}
\begin{abstract}
The National Iron Ore Mining Company Ltd currently operates five mining faces with grades varying from $34.19 \% \mathrm{Fe}$ to $36.44 \% \mathrm{Fe}$. Non-proportionate exploitation from the five ore faces of the pit has led to non-stable grade of ore being fed to the beneficiation plant. The result is that the concentrate being produced continues to vary from $62 \% \mathrm{Fe}$ to $65 \% \mathrm{Fe}$. This variation can affect contractual obligation of the steel company that procures the iron ore concentrate from the National Iron Ore Mining Company. In this paper, mathematical and excel solution have been applied to estimate annual production from each mine face which when blended together will ensure a stable feed of $36 \% \mathrm{Fe}$ to the beneficiation plant. This will in turn ensure stable grade of concentrate coming out of Itakpe beneficiation plant.
\end{abstract}

\section{INTRODUCTION}

For efficient operation of a metallurgical plant, it is necessary that the plant be fed with constant grade of the concentrate coming from beneficiation plant. This is necessary not only to ensure stable energy utilisation by the plant for its longevity but also to ensure that the steel products are of the specified quality that will meet contractual obligations.

For beneficiation plant to produce concentrate of constant grade, it is required that the run-of-mine ore going to the beneficiation plant be maintained at constant grade. If the run-of-mine ores vary in grade, then the concentrate from the beneficiation plant will also vary in grade. But the ores coming from various faces of ore bodies in the mine are of various grades. Thus, it becomes necessary that the ores coming from the faces be blended (homogenized) in a blending yard in order to have an ore of uniform grade. The question is, what tonnage from each face should be mined so that when blended together, an ore of constant grade will be fed to the beneficiation plant.

The National Iron Ore Company Ltd Itakpe mines iron ore from an open-pit mine. The mineable grades of ore vary from $24 \% \mathrm{Fe}$ to $41 \% \mathrm{Fe}$ (Table 1 )

Table1. Ore grades and reserve at Itakpe

\begin{tabular}{|c|c|}
\hline Grade \% & Tonnage mt \\
\hline 34.19 & 15.49 \\
\hline 37.88 & 31.58 \\
\hline 35.01 & 5.22 \\
\hline 29.5 & 0.95 \\
\hline 34.95 & 3.6 \\
\hline 36.44 & 10.68 \\
\hline 40.95 & 6.2 \\
\hline 29.88 & 9.54 \\
\hline 34.42 & 20.1 \\
\hline 37.037 & 32 \\
\hline 38.68 & 2.8 \\
\hline 36.45 & 4.41 \\
\hline 25.3 & 3.8 \\
\hline 34.7 & 4.5 \\
\hline 28.6 & 3.6 \\
\hline 24.4 & 4.6 \\
\hline
\end{tabular}

Source: NIOMCO Project Report, 1980 
The five ore faces being extracted have a grade of $34.19 \% \mathrm{Fe}, 37.88 \% \mathrm{Fe}, 35.01 \% \mathrm{Fe}, 36.44 \% \mathrm{Fe}$, $34.42 \% \mathrm{Fe}$ respectively with a weighted average of $36 \% \mathrm{Fe}$.

The grade of concentrate being fed to Ajaokuta plant varied from 62-65\% Fe (NIOMCO 2000). The essence of this research is therefore to find out the tonnage of each grade of ore coming from each mine face which when blended together will form a constant average grade of $36 \% \mathrm{Fe}$. This will ensure that a concentrate of constant grade is supplied to Ajaokuta Steel Plant to ensure not only the efficient operation of the plant but will also enable the company to meet her contractual obligation in terms of quality of steel products.

\section{MeTHODOLOGY}

The variables to be estimated are the tonnages of ores coming from the various faces. Their values must be such that when blended together, they must provide the grade going to the beneficiation plant as well as provide the annual planned output of the mine.

This can be done by putting forward an objective function with constraints (Sharma J.K 2013), (Rzhesky 1985).

The constraints are to ensure the following:

1. That the tonnage of ore from each face is more than zero i.e all the faces being operated must be involved in the mining operation and blending process.

2. That the sum of ores produced from all the faces annually must provide the designed production rate of the mine.

3. That the ores from various faces when homogenized (blended) must provide the $36 \% \mathrm{Fe}$ going to the beneficiation plant.

The objective function and the constraints are captured in the following equations

\subsection{Objective Function}

$$
\mathrm{F}=\frac{r_{1} q_{1}+r_{2} q_{2}+r_{3} q_{3}+r_{4} q_{4}+r_{5} q_{5}}{q_{1}+q_{2}+q_{3}+q_{4}+q_{5}}
$$

Where;

$$
\begin{aligned}
& q_{1}, q_{2}, q_{3}, q_{4}, q_{5}= \\
& r_{1}, r_{2}, r_{3}, r_{4}, r_{5}=
\end{aligned}
$$

Tonnage of ores required to be mined from each face (variable)

The respective grades of ores $q_{1}, q_{2}, q_{3}, q_{4}, q_{5}$ from each face annually.

The objective function above represents the weighted grade of ores coming from the various faces and should be equal to $36 \% \mathrm{Fe}$ i.e the grade of ore required to be fed to beneficiation plant. Consequently the objective function can be re-written as

$$
\mathrm{F}=\frac{r_{1} q_{1}+r_{2} q_{2}+r_{3} q_{3}+r_{4} q_{4}+r_{5} q_{5}}{q_{1}+q_{2}+q_{3}+q_{4}+q_{5}}=36 \% \mathrm{Fe}
$$

The variables must satisfy the following conditions (constraints)

$$
\begin{aligned}
& \mathrm{q}_{1}>0 \\
& \mathrm{q}_{2}>0 \\
& \mathrm{q}_{3}>0 \\
& \mathrm{q}_{4}>0 \\
& \mathrm{q}_{5}>0 \\
& q_{1}+q_{2}+q_{3}+q_{4}+q_{5} \geq 5 \mathrm{mt}
\end{aligned}
$$

Where;

$5 \mathrm{mt}=\quad$ the scheduled annual production rate of Itakpe mine. 
Ore Production Optimization for Constant Grade of Run-of-Mine Feed to the Beneficiation Plant of National Iron Ore Mining Company, Itakpe, Nigeria

\section{RESULTS AND DISCUSSION}

The National Iron Ore Mining Company is currently operating five faces along five ore bodies with respective grades and reserve as tabulated below

Table2. Grade and reserve of the five ore bodies being exploited

\begin{tabular}{|c|c|}
\hline Grade \% & Tonnage mt \\
\hline 34.19 & 15.49 \\
\hline 37.88 & 31.58 \\
\hline 35.01 & 5.22 \\
\hline 36.44 & 10.68 \\
\hline 34.42 & 20.1 \\
\hline
\end{tabular}

Weighted grade of the five ore bodies is:

$\mathrm{R}=\frac{15.49 \times 34.19+31.58 \times 37.88+5.22 \times 35.01+10.68 \times 36.44+20.1 \times 34.42}{15.49+31.58+5.22+10.68+20.1}=35.99 \bumpeq 36 \% \mathrm{Fe}$

This is the weighted grade of the five ore bodies which is the grade fed to beneficiation plant.

The objective function for blending the ores from the five ore bodies in Itakpe mine therefore becomes

$\mathrm{F}=\frac{34.19 q_{1}+37.88 q_{2}+35.01 q_{3}+36.44 q_{4}+34.42 q_{5}}{q_{1}+q_{2}+q_{3}+q_{4}+q_{5}}$

The objective function is not linear and contains five unknowns $q_{1}, q_{2}, q_{3}, q_{4}, q_{5}$. Since the sum of all the ores coming from the five ore bodies must be equal to five million, the objective function can be made linear by transforming it as follows for excel solution

$$
\mathrm{F}=\frac{34.19 q_{1}}{5}+\frac{37.88 q_{2}}{5}+\frac{35.01 q_{3}}{5}+\frac{36.44 q_{4}}{5}+\frac{34.42 q_{5}}{5}
$$

$\mathrm{F}=6.838 q_{1}+7.576 q_{2}+7.002 q_{3}+7.288 q_{4}+6.884 q_{5}$

The excel solution for the above is given in fig 1 , in which

$\mathrm{q}_{1}=0.8 \mathrm{mt}, \mathrm{q}_{2}=1.1 \mathrm{mt}, \mathrm{q}_{3}=1 \mathrm{mt}, \mathrm{q}_{4}=1.2 \mathrm{mt}, \mathrm{q}_{5}=0.9 \mathrm{mt}$

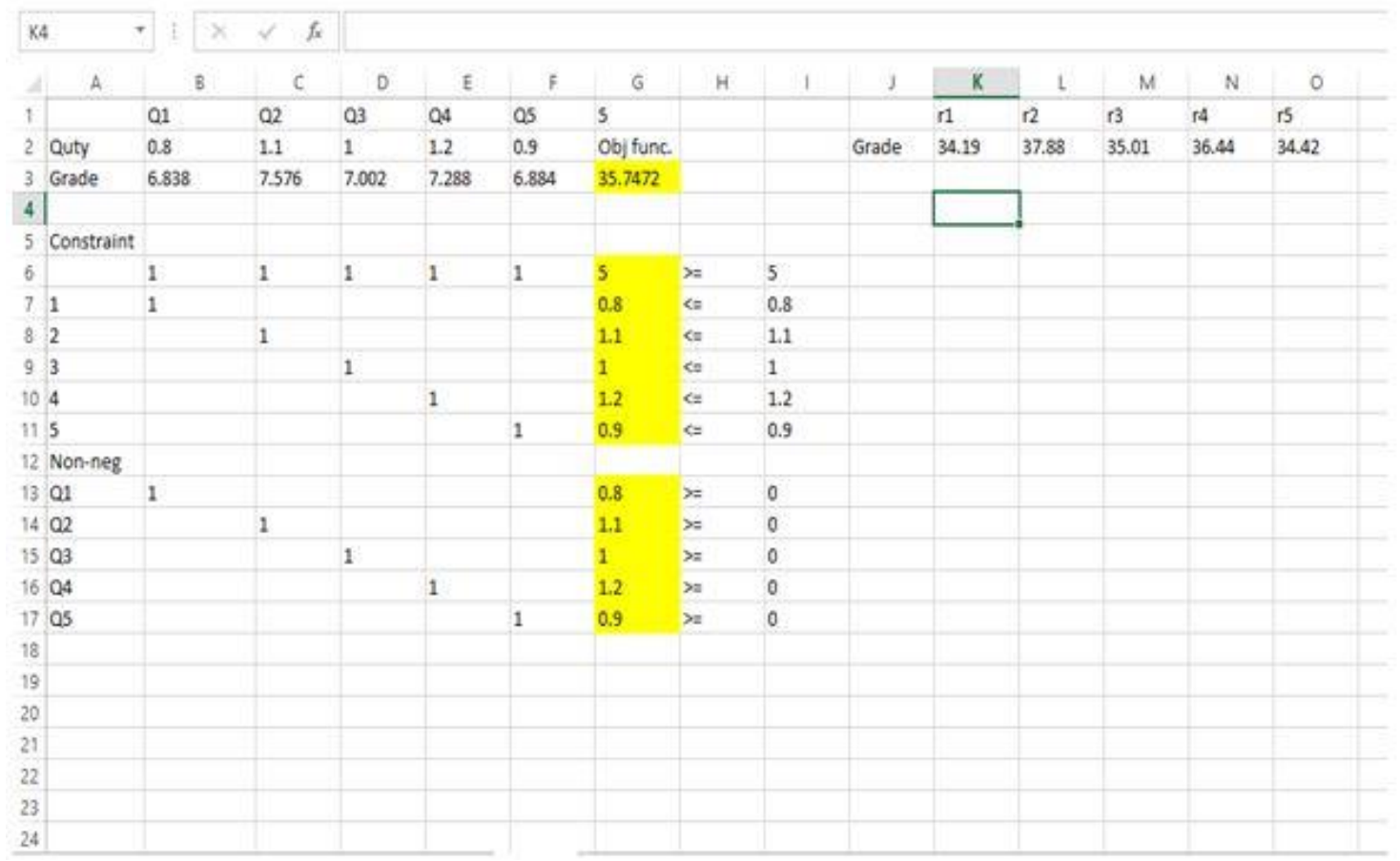

Fig1. Excel solution to the objective function 
Ore Production Optimization for Constant Grade of Run-of-Mine Feed to the Beneficiation Plant of National Iron Ore Mining Company, Itakpe, Nigeria

\subsection{Verification}

$q_{1}+q_{2}+q_{3}+q_{4}+q_{5}=0.8+1.1+1+1.2+0.9=5 \mathrm{mt}$

Objective function $=\frac{34.19 \times 0.8+37.88 \times 1.1+35.01 \times 1+36.44 \times 1.2+34.42 \times 0.9}{0.8+1.1+1+1.2+0.9}$ $\frac{178.8}{5}=35.76 \bumpeq 36 \% \mathrm{Fe}$

The weighted grade of ores required from each face is $35.76 \% \mathrm{Fe}$ as against $35.99 \% \mathrm{Fe}$ which is the weighted grade of the overall reserve from the five ore faces. The difference of $0.23 \% \mathrm{Fe}$ can be explained in terms of the approximation of non-linear function to linear function. This can be corrected by setting $\mathrm{q}_{1}=0.60 \mathrm{mt}$ and $1.3 \mathrm{mt}$. The objective function can be verified again, that is;

$\mathrm{F}=\frac{34.19 \times 0.6+37.88 \times 1.3+35.01 \times 1+36.44 \times 1.2+34.42 \times 0.9}{0.8+1.1+1+1.2+0.9}=35.9 \bumpeq 36 \% \mathrm{Fe}$

The table below summarise the required monthly, quarterly and annual tonnage coming from each face.

Table3. Summary of production requirement from each face to achieve $36 \% \mathrm{Fe}$

\begin{tabular}{|l|c|c|c|c|c|}
\hline & $\mathbf{q}_{\mathbf{1}}$ & $\mathbf{q}_{\mathbf{2}}$ & $\mathbf{q} \mathbf{3}_{\mathbf{3}}$ & $\mathbf{q} \mathbf{4}$ & $\mathbf{q}_{\mathbf{5}}$ \\
\hline Grade (\%Fe) & 34.19 & 37.88 & 35.01 & 36.44 & 34.42 \\
\hline Annual (mt) & 0.6 & 1.3 & 1 & 1.2 & 0.9 \\
\hline Quarterly (mt) & 0.15 & 0.325 & 0.25 & 0.3 & 0.225 \\
\hline Monthly (mt) & 0.05 & 0.082 & 0.063 & 0.1 & 0.06 \\
\hline
\end{tabular}

\section{CONCLUSION}

There should be proportionate exploitation of ores of various grades from the five faces representing five ore bodies currently being exploited. This is the only way to ensure $36 \% \mathrm{Fe}$ ore grade as feed to beneficiation plant. Given the proportionate exploitation of the five ore bodies with various grades, proper blending at blending yard will ensure the supply of stable grade of $36 \% \mathrm{Fe}$ to the beneficiation plant which in turn will ensure stable energy consumption regime and quality of steel products from Ajaokuta Steel Company Ltd, Nigeria.

\section{REFERENCES}

National Iron Ore Mining Project (NIOMCO),1980, Vol. 2 National Iron Ore Mining Company Ltd, Itakpe, Kogi State, Nigeria.

NIOMCO (2000) Status Report, Pp 22.

Sharma J.K (2013), Operations Research Theory and Application,

$5^{\text {th }}$ Edition, Published by Macmillan Publishers India Ltd.

Rzhevsky V.V (1985) Open Cast Mining Unit Operation

Vol 1, Pp 408, Published by Mir Publishers.

Citation: Nwosu J.I, (2020) "Ore Production Optimization for Constant Grade of Run-of-Mine Feed to the Beneficiation Plant of National Iron Ore Mining Company, Itakpe, Nigeria”, International Journal of Mining Science (IJMS), 6(4), pp. 16-19. DOI: http://doi. org/10.20431/2454-9460.0604002

Copyright: (C) 2020 Nwosu J.I, This is an open-access article distributed under the terms of the Creative Commons Attribution License, which permits unrestricted use, distribution, and reproduction in any medium, provided the original author and source are credited. 